\title{
Evidence that androgens are involved in atresia and anovulation induced by antiprogesterone RU486 in rats
}

\author{
J. E. Sánchez-Criado, M. Tébar, A. Sánchez and F. Gaytán \\ Department of Physiology and Biology Section, Faculty of Medicine, University of Córdoba, \\ 14004 Córdoba, Spain
}

\begin{abstract}
Administration of antiprogesterone RU486 to female cyclic rats results in blockade of ovulation associated with both a decreased ovulatory release of LH and an increased rate of follicular atresia. These rats also exhibit increased LH:FSH and testosterone:oestradiol ratios in serum during the period of follicular development as well as an increase in serum concentrations of prolactin that can be suppressed by a dopamine agonist. The increase in either prolactin or testosterone concentrations as well as the relative deficiency in FSH might be responsible for the increase in follicular atresia. The present work evaluated the involvement of $\mathrm{LH}, \mathrm{FSH}$, prolactin and testosterone in follicular atresia and in blockade of ovulation induced by RU486 in the cyclic rat. Although bromocriptine treatment did not modify the blockade of ovulation induced by RU486, unilateral ovariectomy at metoestrus and antiandrogen flutamide treatment reversed, in part, the effects of RU486 on both follicular development and ovulation. The combined increase in FSH serum concentration during dioestrus induced by unilateral ovariectomy and the treatment with flutamide had no additive effects. Furthermore, treatment with a superovulatory amount of hFSH did not reverse the effects of RU486. Moreover, unilateral ovariectomy halved testosterone serum concentrations and flutamide treatment had no effect on LH and FSH concentrations in RU486-treated rats. It was therefore concluded that androgens play a role, at least in part, in the process of follicular atresia induced by RU486.
\end{abstract}

\section{Introduction}

Administration of the antiprogesterone RU486 during the dioestrous phase of cyclic rats produces ovulatory impairment (Rao and Mahesh, 1986; Sánchez-Criado et al., 1990, 1992b; Uilenbroek, 1991). This effect of RU486 is dose dependent. Although $0.2 \mathrm{mg}$ RU486 day ${ }^{-1}$ has no effect and $10 \mathrm{mg}$ RU486 day $^{-1}$ is fully effective in blocking ovulation, $2 \mathrm{mg}$ RU486 day $^{-1}$ reduces both the number of rats ovulating and the number of ova per ovulating rat (Sánchez-Criado et al., 1990).

The antiprogesterone RU486 also induces a reduction in the amount of ovulatory LH released (Rao and Mahesh, 1986; Sánchez-Criado et al., 1990; Uilenbroek, 1991; Knox and Schwartz, 1992) as well as inadequate follicular development at the time of the LH surge (Sánchez-Criado et al., 1990). On the basis of this evidence, a dual mechanism has been proposed for the anovulatory action of RU486 in rats (Sánchez-Criado et al., 1990). While reduction in the ovulatory LH released itself justifies the action of RU486 on ovulation, it is not clear by what mechanism the follicular responsiveness is reduced by RU486 treatment.

Moreover, administration of RU486 to cyclic rats increases basal concentrations of LH (Sánchez-Criado et al., 1990; Uilenbroek, 1991), reduces those of FSH (Sánchez-Criado $e t$ al., $1990,1992 a)$ and increases serum testosterone:oestradiol ratio

Received 10 November 1992
(Sánchez-Criado et al., 1992b). Furthermore, treatment with RU486 results in increased secretion of prolactin (van der Schoot et al., 1987).

Follicular development is under a complex regulatory process (reviewed by Greenwald and Terranova, 1988) and pituitary gonadotrophins (LH, FSH and prolactin) and ovarian steroids are the major regulators of follicular development (reviewed by Hsueh et al., 1984). The aim of these studies was to investigate further the mechanism of RU486-induced follicular atresia and, hence, ovulatory failure in cyclic rats.

\section{Materials and Methods}

Animals

Experiments were performed with adult female Wistar rats (body weight between 200 and $230 \mathrm{~g}$ ). Animals were housed under standard conditions of light (lights-on: 07:00-19:00 h) and temperature $\left(20-22^{\circ} \mathrm{C}\right.$ ). Rats were examined daily for vaginal smears. Only those rats showing at least two consecutive 4-day oestrous cycles were used.

\section{Materials}

Antiprogesterone RU486, $11 \beta$-(4-dimethylaminophenyl)-17 $\beta$ hydroxy-17 $\alpha$-(1-propinyl)-oestra-4,9-diene-3-one (Roussel-Uclaf, 
Romainville) (Baulieu, 1991) was suspended in olive oil at a concentration of $20 \mathrm{mg} \mathrm{ml}^{-1}$. Rats in these experiments were given $4 \mathrm{mg}$ in $0.2 \mathrm{ml} \mathrm{s.c.} \mathrm{injections} \mathrm{daily} \mathrm{starting} \mathrm{on} \mathrm{the} \mathrm{day} \mathrm{of}$ metoestrus (09:00 h) through the day of pro-oestrus. Control rats received $0.2 \mathrm{ml}$ oil. The dose of RU486 used was derived from a dose-response effect of this compound on the ovulation rate in rats (Sánchez-Criado et al., 1990).

Bromocriptine (Sigma Chemical Co., St Louis, MO) was dissolved at a concentration of $4 \mathrm{mg} \mathrm{ml}^{-1}$ in $70 \%$ ethanol. Rats were injected (s.c.) with $1 \mathrm{mg}$ bromocriptine in $0.25 \mathrm{ml}$ at metoestrus, dioestrus and pro-oestrus. This dose is sufficient to block the secretion of prolactin during dioestrus (Sánchez-Criado et al., 1986).

Flutamide, 4'-nitro-3'-trifluoromethyl-isobutyranilide (ScheringPlough, Madrid) was dissolved at a concentration of $10 \mathrm{mg}$ $\mathrm{ml}^{-1}$ in $70 \%$ ethanol. Rats were given $0.2 \mathrm{ml}$ (s.c.) at metoestrus, dioestrus and pro-oestrus. This dose completely blocks the action of testosterone (Chandolia et al., 1991).

Highly purified human FSH (hFSH) (Metrodin: Serono, Aubonne) was dissolved at a concentration of $50 \mathrm{iu} \mathrm{m} \mathrm{ml}^{-1}$ saline. Rats were injected (s.c.) twice a day (09:00 and 17:00 h) at metoestrus and dioestrus with $0.1 \mathrm{ml}$ of this solution. Characteristics of this preparation have been described elsewhere (Chandolia et al., 1991).

Human chorionic gonadotrophin (hCG) (Pregnyl, Organon, OSS, The Netherlands) was given (10 iu s.c.) at 17:00 h at prooestrus. Before the hCG injection, an i.p. injection of sodium pentobarbital ( $35 \mathrm{mg} \mathrm{kg}^{-1}$ body weight) was given at 15:00 $\mathrm{h}$ to block the endogenous LH surge. Oil-treated rats were injected with either sodium pentobarbital or with sodium pentobarbital and hCG to check the effectiveness of both compounds. The ovulatory response was measured on the following day.

\section{Surgery}

Unilateral ovariectomy was performed under ether anaesthesia at 09:00 h on the day of metoestrus to increase FSH concentrations temporarily. Control rats were sham-operated.

\section{Experiments}

Experiment 1 was designed to measure both basal and preovulatory serum concentrations of $\mathrm{LH}, \mathrm{FSH}$ and prolactin in rats injected with oil or RU486. They were decapitated at prooestrus either at 09:00 h or at 19:30 h the time at which the maximum preovulatory surge of LH was observed). Trunk blood was collected to measure tonic $(09: 00 \mathrm{~h})$ and surge (19:30 h) secretion of LH, FSH and prolactin.

In Expt 2, blood samples were collected from rats injected with oil or RU486 by direct jugular venepuncture under light ether anaesthesia at 09:00 h at metoestrus, dioestrus and prooestrus to measure basal serum concentrations of progesterone, testosterone and oestradiol.

Experiment 3 studied the effects of an ovulatory injection of hCG, unilateral ovariectomy, bromocriptine, flutamide or hFSH treatments on the ovulation rate in rats treated with RU486 from metoestrus to pro-oestrus. Additional RU486-treated rats with combined treatments (unilateral ovariectomy + flutamide, unilateral ovariectomy $+\mathrm{hCG}$ and flutamide $+\mathrm{hCG}$ ) were also used. Rats in this experiment were decapitated on the next day (oestrus) and checked for ovulation.

In Expt 4, the effects of RU486 on follicular development and the effect of unilateral ovariectomy and flutamide treatment on RU486-induced follicular atresia were studied. These rats were decapitated at $16: 30 \mathrm{~h}$ at pro-oestrus and their ovaries processed for histology to examine the effects of RU486 on follicular development.

In Expt 5, rats treated with RU486 were unilaterally ovariectomized or sham-operated at 09:00 h at metoestrus, to determine whether unilateral ovariectomy modifies serum testosterone concentration and whether flutamide affects serum LH and FSH concentrations in RU486-treated rats. Another group of intact rats treated with RU486 were injected with flutamide or vehicle. Rats in this experiment were decapitated at 09:00 $\mathrm{h}$ at pro-oestrus and blood was collected to determine serum concentration of testosterone, $\mathrm{LH}$ and FSH.

\section{Ovulation}

The Fallopian tubes were exposed and the ampullary region was examined for the presence of eggs, and the number of ova counted to assess ovulation.

\section{Ovarian histology}

Both ovaries from four rats per group were carefully dissected, fixed with Bouin-Hollande's fluid and after dehydration, embedded in paraffin wax. The ovaries were serially sectioned (10 $\mu \mathrm{m}$ thick) and stained with haematoxylin and eosin. The follicular diameter was determined with the aid of an ocular micrometer. Two diameters at right angles were measured in each follicle in the follicular section containing the oocyte nucleolus or chromatin mass. The number and mean diameter of follicles measuring more than $550 \mu \mathrm{m}$ were recorded. These corresponded to large antral follicles. Follicles were classified as atretic when they showed alterations in the oocyte or granulosa cells, following previously established criteria (Osman, 1985; Sánchez-Criado et al., 1990).

\section{Collection of blood samples}

Blood samples were allowed to clot, and were then centrifuged $(2000 \mathrm{~g}, 20 \mathrm{~min})$ at $4^{\circ} \mathrm{C}$. Serum samples were stored at $-20^{\circ} \mathrm{C}$ until assayed.

\section{Hormone assays}

Concentrations of LH, FSH and prolactin were measured in $25 \mu \mathrm{l}$ serum samples by double-antibody radioimmunoassay (Sánchez-Criado et al., 1990) with kits supplied by $\mathrm{NIH}$ (Bethesda, MD). Rat LH-I-6, FSH-1-6 and PRL-I-5 were labelled with ${ }^{125} \mathrm{I}$ by the chloramine $\mathrm{T}$ method. $\mathrm{LH}, \mathrm{FSH}$ and prolactin values are expressed as $\mathrm{ng} \mathrm{m} \mathrm{m}^{-1}$ of the reference preparations LH-rat-RP-2, FSH-rat-RP-2 and PRL-rat-RP-3, respectively. The sensitivity of assays was $7.5,20$, and $10 \mathrm{pg}$ per tube for LH, FSH and PRL, respectively. 
Serum progesterone concentration was determined in duplicate with antiserum GDN337 from G.D. Niswender (Colorado State University, Fort Collins, CO) as described previously (Gibori et al., 1977; Sánchez-Criado et al., 1986). Values are expressed as $\mathrm{nmol} \mathrm{l}^{-1}$. Serum concentrations of testosterone and oestradiol were determined using commercially obtained kits (Diagnostic Products Corporation, Los Angeles, CA). Values are expressed as nmol $1^{-1}$ and pmol $1^{-1}$ for testosterone and oestradiol, respectively.

All samples were assayed in the same specific assay and the intra-assay coefficients of variation were $9,6,9,9,7$ and $8 \%$ for $\mathrm{LH}, \mathrm{FSH}$, prolactin, progesterone, testosterone and oestradiol, respectively.

\section{Statistical analysis}

Results given in the text are expressed as means \pm SEM. Differences between groups were compared by Student's $t$ test or analysis of variance (ANOVA) followed by Duncan's multiple range test. When appropriate, the nonparametric Fisher's exact probability test was used. Values of $P>0.05$ were not considered significant.

\section{Results}

Serum concentrations of gonadotrophins and steroids in

\section{RU486-treated rats}

The antiprogesterone RU486 increased serum concentrations of $\mathrm{LH}$ and prolactin significantly while decreasing FSH serum concentration on the morning of pro-oestrus (Fig. I). At 19:30 h at pro-oestrus both LH and FSH serum concentrations were significantly reduced in RU486-treated rats compared with oiltreated rats. No differences in prolactin serum concentration were noted between the two groups.

No effects of RU486 on serum concentrations of progesterone were noted throughout dioestrus (Fig. 2). On the contrary, serum concentrations of testosterone increased significantly in RU486-treated rats compared with controls at dioestrus and pro-oestrus. Serum concentrations of oestradiol increased only at pro-oestrus (Fig. 2).

Effects of hCG, bromocriptine, unilateral ovariectomy, flutamide and hFSH on ovulation in RU486-treated rats

Treatment with RU486 caused a blockade of ovulation. An injection of 10 iu hCG restored, in part, the number of rats ovulating and the number of ova per ovulating rat. Administration of the dopamine agonist bromocriptine did not affect the ovulation rate in either oil- or RU486-treated rats.

Both unilateral ovariectomy and flutamide treatment reversed in part the blockade of ovulation by RU 486 but the combined procedures did not have additive effects on ovulation. While hFSH treatment induced superovulation in oiltreated rats, it had no effect in RU486-treated rats. The combined treatments were not significantly more efficient in reversing the blockade of ovulation by RU486 than either treatment alone (Table 1 ).
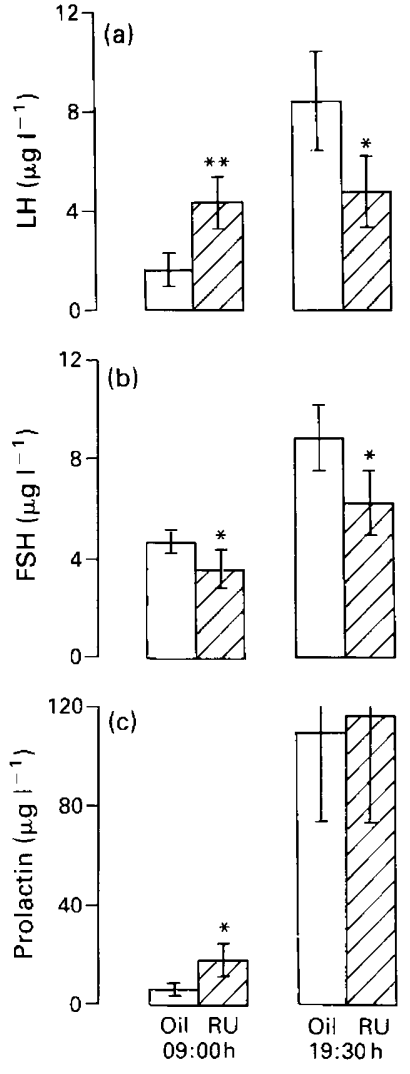

Pro-oestrus

Fig. 1. Effect of RU486 on serum concentration (mean \pm SEM) of (a) LH, (b) FSH and (c) prolactin in 09:00 and 19:30 h at pro-oestrus ( $n=7-9$ ). Rats were injected with ( $\square$ ) $0.2 \mathrm{ml}$ of oil or with ( $\square$ ) $4 \mathrm{mg}$ RU486 at 09:00 h at metoestrus, dioestrus and pro-oestrus. ${ }^{*} P<0.05$ and ${ }^{* *} P<0.01$ compared with control group (Student's $t$ test).

Effect of unilateral ovariectomy and fiutamide on testosterone and gonadotrophin serum concentration, respectively, at 09:00 hat pro-oestrus in RU486-treated rats

Unilateral ovariectomy significantly $(P<0.05$, Student's $t$ test) reduced serum concentration of testosterone at 09:00 h at pro-oestrus in rats treated with RU486 $\left(721 \pm 86 \mathrm{nmol} \mathrm{1}^{-1}\right.$, $n=8$ ) when compared with the effect of sham-operation $\left(1240 \pm 144 \mathrm{nmol} \mathrm{l}^{-1}, n=8\right)$. Flutamide treatment had no effect on either $\mathrm{LH}\left(4.4 \pm 0.4 \mathrm{ng} \mathrm{ml} \mathrm{m}^{-1}, n=9\right)$ or $\mathrm{FSH}$ $\left(2.0 \pm 0.1 \mathrm{ng} \mathrm{ml}^{-1}, n=9\right)$ serum concentration at $09: 00 \mathrm{~h}$ at pro-oestrus in rats treated with RU486 compared with those of rats injected with flutamide vehicle $\left(\mathrm{LH}=5.7 \pm 0.7 \mathrm{ng} \mathrm{ml}^{-1}\right.$; $\mathrm{FSH}=2.3 \mathrm{ng} \mathrm{ml}^{-1}, n=9$ ).

Effects of unilateral ovariectomy and flutamide on follicular development in RU486-treated rats at $16: 30 \mathrm{~h}$ at pro-oestrus

Light microscopy studies showed that oil (Fig. 3a), unilaterally ovariectomized (not shown) and flutamide-treated (not shown) rats contained healthy antral follicles with the oocyte in the germinal vesicle or chromatin mass I stages. Atretic large antral follicles were rarely observed. Rats treated with RU486 showed abundant atretic large antral follicles. Alterations in 

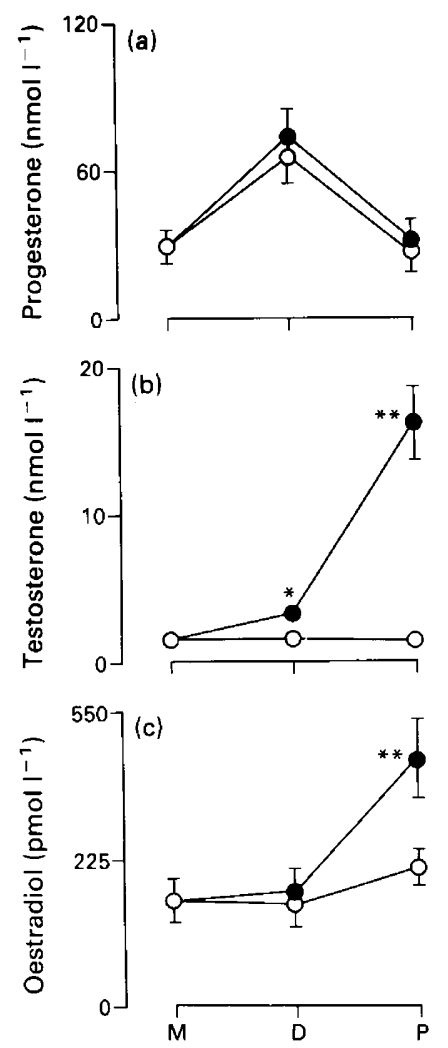

Fig. 2. Effect of RU486 on serum concentration (mean \pm SEM) of (a) progesterone, (b) testosterone and (c) oestradiol at 09:00 h at (M) metoestrus, (D) dioestrus and (P) pro-oestrus $(n=8)$. Rats were injected with (O) oil or with (O) RU486 at 09:00 h at metoestrus and dioestrus. ${ }^{*} P<0.05$ and ${ }^{* *} P<0.01$ compared with control group (Student's $t$ test).

these follicles varied among and within animals. Most of the follicles showed alterations in that the granulosa cell layer was virtually absent in some areas and formed accumuli in other areas (Fig. 3b). In some follicles, the granulosa cell layer was separated from the theca cell layer and detached granulosa cells were observed in the follicular cavity (Fig. 3c, d). Other follicles showed different degrees of luteinization (Fig. 3e). The wall of these follicles showed areas of large acidophilic cells (Fig. 3f). Oocytes in these follicles were in the same maturational stage as those of healthy follicles. Cumulus dispersion was observed in those follicles undergoing extensive luteinization (Fig. 3e).

No differences in the number of large antral follicles per rat were found between oil- and RU486-treated rats (Table 2). The number of atretic follicles was significantly higher in RU486-treated rats. Flutamide and, to a lesser degree, unilateral ovariectomy decreased the number of atretic follicles in RU486-treated rats.

\section{Discussion}

The finding that injection with an ovulatory dose of $\mathrm{hCG}$ in rats treated with $4 \mathrm{mg}$ RU486 a day reversed only in part the number of rats ovulating and the number of ova per ovulating
Table 1. Effects of hCG, unilateral ovariectomy (ULO), bromocriptine (BCR), flutamide (FLT) and hFSH on ovulation rate at 09:00 $\mathrm{h}$ at oestrus in RU486-treated rats

\begin{tabular}{lcc}
\hline Group & $\begin{array}{c}\text { Proportion } \\
\text { of rats } \\
\text { ovulating }\end{array}$ & $\begin{array}{c}\text { Number of } \\
\text { ova per } \\
\text { ovulating rat }\end{array}$ \\
\hline Oil & $9 / 9$ & $13.8 \pm 1.0$ \\
RU486 & $0 / 9$ & - \\
Oil + PBT & $0 / 8$ & - \\
Oil + PBT + hCG & $8 / 8$ & $14.1 \pm 1.7$ \\
RU486 + PBT + hCG & $2 / 8^{\mathrm{a}}$ & $3.5 \pm 0.4^{\mathrm{c}}$ \\
Oil + BCR & $7 / 7$ & $14.1 \pm 0.6$ \\
RU486 + BCR & $0 / 7$ & - \\
Oil + ULO & $7 / 7$ & $15.0 \pm 1.0$ \\
RU486 + ULO & $3 / 9^{\mathrm{a}}$ & $9.7 \pm 1.5^{\mathrm{c}}$ \\
Oil + FLT & $5 / 5$ & $13.2 \pm 0.4$ \\
RU486 + FLT & $5 / 8^{\mathrm{b}}$ & $7.4 \pm 2.8^{\mathrm{c}}$ \\
Oil + hFSH & $6 / 6$ & $29.5 \pm 8.1^{\mathrm{d}}$ \\
RU486 + hFSH & $0 / 7$ & - \\
RU486 + ULO + FLT & $5 / 8^{\mathrm{b}}$ & $7.3 \pm 2.5^{\mathrm{c}}$ \\
RU486 + ULO + PBT + hCG & $3 / 7^{\mathrm{b}}$ & $7.4 \pm 4.0^{\mathrm{c}}$ \\
RU486 + FLT + PBT + hCG & $5 / 8^{\mathrm{b}}$ & $9.6 \pm 2.0^{\mathrm{c}}$ \\
\hline
\end{tabular}

RU486 (4 mg) or oil $(0.2 \mathrm{ml})$ was injected (s.c.) at 09:00 h at metoestrus, dioestrus and pro-oestrus. PBT (pentobarbital), $35 \mathrm{mg} \mathrm{kg}^{-1}$ body weight, was injected (i.p.) at 15:00 h at pro-oestrus. hCG (10 iu in $0.1 \mathrm{ml}$ saline) was given (s.c.) at $17: 00 \mathrm{~h}$ at pro-oestrus. Bromocriptine $(1 \mathrm{mg})$ or ethanol $70 \%(0.25 \mathrm{ml})$ was injected (s.c.) at 09:00 $\mathrm{h}$ at metoestrus, dioestrus and pro-oestrus.

Unilateral ovariectomy was performed at $09: 00 \mathrm{~h}$ at metoestrus.

Flutamide $(2 \mathrm{mg})$ or ethanol $70 \%(0.2 \mathrm{ml})$ was injected (s.c.) at 09:00 $\mathrm{h}$ on metoestrus, dioestrus and pro-oestrus.

hFSH (5 iu in $0.1 \mathrm{ml}$ saline) was injected (s.c.) twice a day at metoestrus and dioestrus.

${ }^{*}$ Data represent means \pm SEM.

${ }^{2} P<0.01$ versus RU486-treated rats (Fisher's exact probability test).

${ }^{\mathrm{b}} P<0.05$ versus RU486-treated rats (Fisher's exact probability test).

$c P<0.01$ versus RU486-treated rats (ANOVA and Duncan's multiple range test).

${ }_{d} p<0.01$ versus oil-injected rats (ANOVA and Duncan's multiple range test).

rat agrees with the effect of hCG in rats treated with $2 \mathrm{mg}$ RU486 day $^{-1}$ (Uilenbroek, 1991). In the latter experiment, hCG totally reversed the number of rats ovulating and doubled the number of ova per ovulating rat with respect to our results. Uilenbroek et al. (1992) could not find morphological signs of atresia on the morning of pro-oestrus, although the follicles were already functionally atretic. The most likely explanation for this discrepancy is differences in the dose of RU486 and in the time of autopsy. Overall, the results of these experiments confirmed that the reduction in the preovulatory release of $\mathrm{LH}$ without shifting the time of the LH surge (Sánchez-Criado et al., 1990) in RU486-treated 4-day cyclic rats is, in part, responsible for the effects of RU486 on ovulation.

Rats treated with RU486 exhibited increased basal serum concentrations of $\mathrm{LH}$ and prolactin and decreased basal serum concentrations of FSH (Sánchez-Criado et al., 1990; SánchezCriado et al., 1992a; this study). In addition, these rats presented increased dioestrus and early pro-oestrous serum concentration of testosterone as well as oestradiol, coming from interstitial and luteal compartments (Sánchez-Criado et al., 1992b), respectively. Whereas oestradiol has mitogenic and anti-atretic effects 

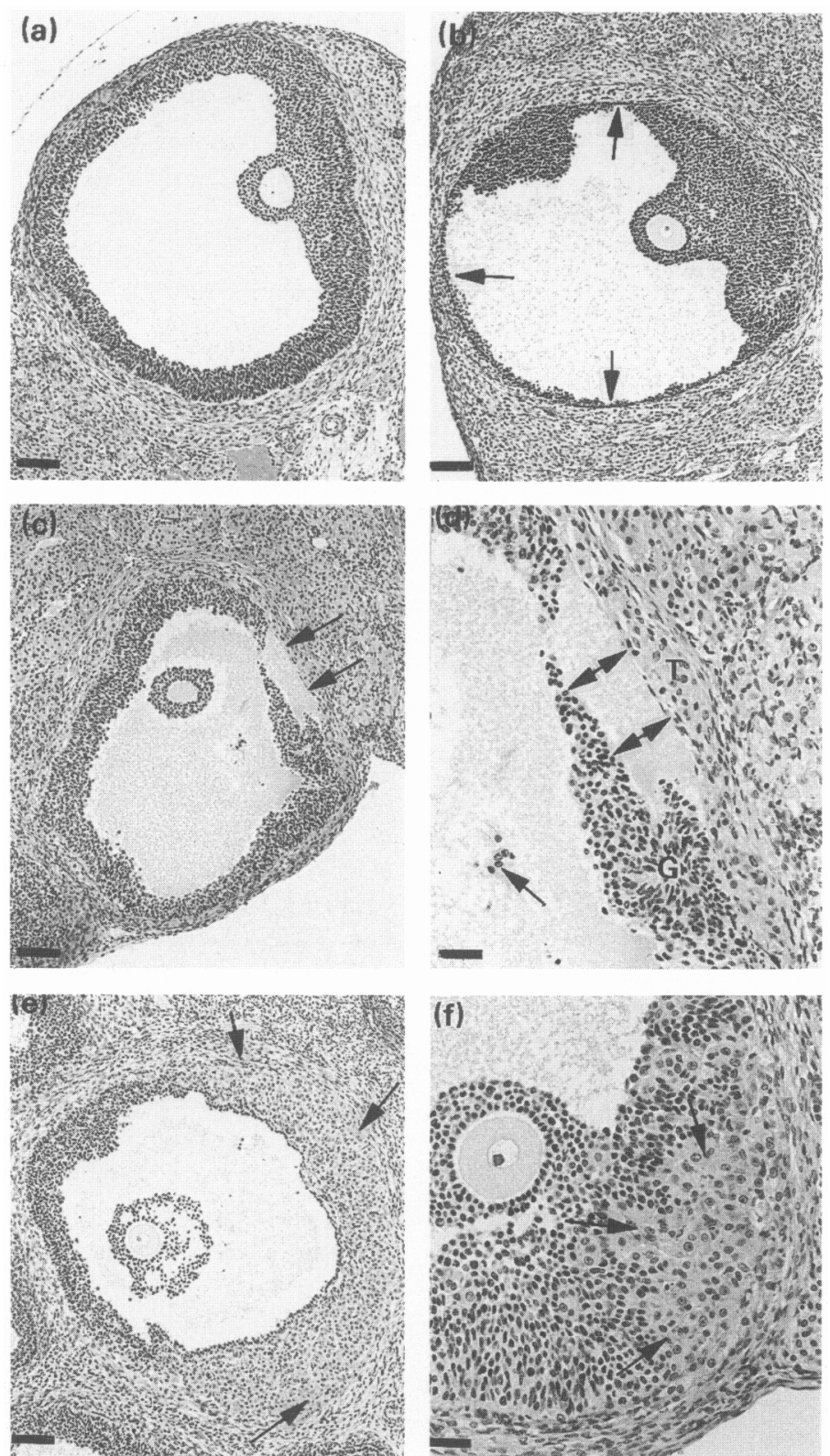

Fig. 3. Micrographs of ovaries at $16: 30 \mathrm{~h}$ on the day of pro-oestrus of rats injected (s.c.) with (a) oil or (b-f) RU486 (4 mg in $0.2 \mathrm{ml}$ oil) at 09:00 h at metoestrus, dioestrus and pro-oestrus. (a) Normal large antral follicle (bar = $75 \mu \mathrm{m}$ ). (b) Atretic large antral follicle showing abnormal granulosa cell layer (arrows) (bar $=75 \mu \mathrm{m}$ ). (c) Atretic large antral follicle showing separation of the granulosa and theca cell layers (arrows) (bar $=75 \mu \mathrm{m}$ ). (d) Detail of Fig. c showing the cleavage (double arrows) between granulosa $(G)$ and theca $(T)$ cell layers and detached granulosa cells (arrow) in the follicular cavity (bar $=30 \mu \mathrm{m}$ ). (e) Partially luteinized follicle (arrows) with early cumulus dispersion (bar $=75 \mu \mathrm{m}$ ). (f) Greater magnification of a large antral follicle showing an area of luteinized granulosa cells (arrows) (bar $=30 \mu \mathrm{m}$ ).

(Harman et al., 1975), prolactin, androgens and the relative deficiency of FSH all promote follicular atresia (reviewed by Hsueh et al., 1984).

It is known that prolactin inhibits follicular development (Dorrington and Gore-Langton, 1982; Kalison et al., 1985) and that bromocriptine reverses this effect of prolactin (Uilenbroek and van der Linden, 1984). Our findings indicate that the increase in basal prolactin serum concentrations in RU486treated rats is not involved in the anovulatory action of RU486, probably because the RU486-induced hyperprolactinaemia was not severe.

As previously described for cyproterone acetate (Neumann et al., 1970), the non-steroidal anti-androgen flutamide had no effect on ovulation in oil-treated rats, and reversed, in part, 
Table 2. Effects of unilateral ovariectomy (ULO) and flutamide (FLT) treatment on follicular development at $16: 30 \mathrm{~h}$ at pro-oestrus in RU486-treated rats

\begin{tabular}{lccc}
\hline Group & $\begin{array}{c}\text { Number of } \\
\text { large antral } \\
\text { follicles per rat }\end{array}$ & $\begin{array}{c}\text { Mean follicular } \\
\text { diameter } \\
(\mu \mathrm{m})\end{array}$ & $\begin{array}{c}\text { Percentage } \\
\text { of atresia }\end{array}$ \\
\hline Oil & $16.5 \pm 1.4$ & $622.0 \pm 20.2$ & $2.7 \pm 1.5$ \\
RU486 & $17.5 \pm 1.4$ & $670.3 \pm 58.9$ & $59.0 \pm 13.7^{\mathrm{a}}$ \\
Oil + ULO & $14.5 \pm 0.3$ & $579.7 \pm 4.1$ & $0.3 \pm 0.2$ \\
RU486 + ULO & $16.0 \pm 1.3$ & $626.1 \pm 22.4$ & $31.9 \pm 4.1^{2.5}$ \\
Oil + FLT & $18.0 \pm 1.1$ & $595.1 \pm 4.4$ & $2.5 \pm 1.4$ \\
RU486 + FLT & $15.2 \pm 0.7$ & $614.1 \pm 5.6$ & $16.6 \pm 5.8^{\mathrm{b} . \mathrm{d}}$ \\
\hline
\end{tabular}

RU486 (4 mg) or oil $(0.2 \mathrm{ml})$ was injected (s.c.) at 09:00 h at metoestrus, dioestrus and pro-oestrus.

Unilateral ovariectomy was performed at 09:00 h at metoestrus. Flutamide $(2 \mathrm{mg})$ or ethanol $70 \%(0.2 \mathrm{ml})$ was injected (s.c.) at 09:00 h at metoestrus, dioestrus and pro-oestrus. Data represent means \pm SEM (four rats per group). ${ }^{a} P<0.01$, ${ }^{b} P<0.05$ versus oil-injected rats and $c p<0.05,{ }^{d} P<0.01$ versus RU486-injected rats (ANOVA and Duncan's multiple range test).

the effects of RU486 in the induction of follicular atresia and the reduction of ovulation without apparent significant effect on LH and FSH concentrations in serum. This indicates that androgen may be involved in the failure of ovulation in the RU486-treated rats.

Unilateral ovariectomy at metoestrus in cyclic rats increases serum concentrations of FSH during dioestrus and reduces those of progesterone without significantly altering serum concentrations of LH and oestradiol (Labhsetwar, 1969; Chatterjee and Greenwald, 1971; Ramirez and Sawyer, 1974; Butcher, 1977; Welschen et al., 1978; Ackland et al., 1990). It is also known that FSH is necessary to promote normal follicular development (Zeleznik et al., 1974, 1979; Hillier et al. 1980). These facts together with the finding that unilateral ovariectomy partially reversed the effects of RU486 in the induction of follicular atresia and the reduction of ovulation also point to the decreased basal FSH serum concentration in RU486-treated rats as partially responsible for the ovulatory deficit.

However, administration of superovulatory doses of hFSH failed to neutralize the effects of RU486 on ovulation; the rise in FSH secretion after unilateral ovariectomy is blunted in RU486-treated rats (Sánchez-Criado et al., 1992a) and unilateral ovariectomy in RU486-treated rats does not affect serum LH concentration (Sánchez-Criado et al., 1992a) but reduces testosterone concentration (see results), as does unilateral orchidectomy in intact male rats (Rivier et al., 1989). Data from these studies support the conclusion that RU486-induced follicular abnormalities are in part mediated through androgen. Furthermore, granulosa cells have specific androgen receptors (Schreiber and Ross, 1976) and androgens are very well known atretogenic factors (Louvet et al., 1975; Hillier and Ross, 1979; Bagnell et al., 1982).

The increased basal concentrations of LH may be the cause of partial luteinization in rats treated with RU486. The time of autopsy (16:30 h at pro-oestrus), which is close to the preovulatory rise in LH in our colony (Sánchez-Criado et al., 1990), may be connected with the histological signs of follicular maturation.
These experiments corroborate the proposed dual anovulatory action of RU486 in rats (Sánchez-Criado et al., 1990) and they strongly suggest that androgens are involved in the RU486induced follicular atresia and, hence, ovulation failure. However, because flutamide treatment combined with the ovulatory injection of hCG did not completely reverse the effect of RU 486 on ovulation, other factors associated with the blockade of progesterone action must participate in the anovulatory effect of RU486. In this regard, the anti-folliculogenic action of the inappropriately high concentrations of LH (Harman et al., 1975; Hillier, 1990) and the absence of progesterone actions on follicular development (Taya et al., 1981; Richards and Bogovich, 1982) and in the final steps of follicular rupture (Iwamasa et al., 1992) are additional factors that are probably involved in the effects of RU486 on ovulation in rats.

The authors wish to thank R. Deraedt (Roussel-Uclaf, Romainville) for the gift of RU486, R. Gonzalez (Schering Plough, Madrid) for the supply of flutamide, G. D. Niswender (Colorado State University, Fort Collins, $\mathrm{CO}$ ) for the generous supply of progesterone antiserum GDN-337 used in the progesterone radioimmunoassay and J. A. F. Tresguerres for the supply of Metrodin. They also wish to express their appreciation to the NIADDK (Baltimore, MD) for the LH, FSH and PRL kits. The critical comments of J. Uilenbroek are cordially appreciated. This work has been subsidized by grant PM92-0118 from DGICYT (Spain).

\section{References}

Ackland JF, D'Agostino J, Ringstrom SJ, Hostetler JP, Mann BG and Schwartz NB (1990) Circulating radioimmunoassayable inhibin during periods of transient follicle-stimulating hormone rise: secondary surge and unilateral ovariectomy Biology of Reproduction 43 347-352

Bagnell CA, Mills TM, Costoff A and Mahesh VB (1982) A model for the study of androgen effects on follicular atresia and ovulation Biology of Reproduction 27 903-914

Baulieu EE (1991) The antisteroid RU486: its cellular and molecular mode of action Trends in Endocrinology and Metabolism 2 233-239

Butcher RL (1977) Changes in gonadotropins and steroids associated with unilateral ovariectomy of the rat Endocrinology 101 830-840 
Chandolia RK, Weinbauer GF, Fingscheidt U, Bartlett JMS and Nieschlag E (1991) Effects of flutamide on testicular involution induced by an antagonist of gonadotrophin-releasing hormone and on stimulation of spermatogenesis by follicle-stimulating hormone in rats journal of Reproduction and Fertility 93 313-323

Chatterjee A and Greenwald GS (1971) Compensatory ovarian hypertrophy following unilateral ovariectomy of the pseudopregnant or pregnant rat Endocrinology 88 491-496

Dorrington JH and Gore-Langton RE (1982) Antigonadal action of prolactin: further studies on the mechanism of inhibition of follicle-stimulating hormone-induced aromatase activity in rat granulosa cell cultures Endocrinology 110 1701-1707

Gibori G, Antczak E and Rothchild I (1977) The role of estrogen in the regulation of luteal progesterone secretion in the rat after day 12 of pregnancy Endocrinology 100 1483-1495

Greenwald GS and Terranova PF (1988) Follicular selection and its control In The Physiology of Reproduction pp 387-445 Eds E Knobil and JD Neill. Raven Press, New York

Harman SM, Louvet J-P and Ross GT (1975) Interaction of estrogen and gonadotropins on follicular atresia Endocrinology 96 1145-1152

Hillier SG (1990) Ovarian manipulation with pure gonadotrophins Journal of Endocrinology 127 1-4

Hillier SG and Ross GT (1979) Effects of exogenous testosterone on ovarian weight, follicular morphology and intraovarian progesterone concentration in estrogen-primed hypophysectomized immature female rats Biology of Reproduction 20 26I-268

Hillier SG, Zeleznik AJ, Knazek RA and Ross GT (1980) Hormonal regulation of preovulatory follicle maturation in the rat Joumal of Reproduction and Fertility $60219-229$

Hsueh AJW, Adashi EY, Jones PBC and Welsh TH Jr (1984) Hormonal regulation of the differentiation of cultured ovarian granulosa cells Endocrine Reviews 5 $76-127$

Iwamasa J, Shibata S, Tanaka N, Matsuura K and Okamura H (1992) The relationship between ovarian progesterone and proteolytic enzyme activity during ovulation in the gonadotropin-treated immature rat Biology of Reproduction 46 309-313

Kalison B, Warshaw ML and Gibori G (1985) Contrasting effects of prolactin on luteal and follicular steroidogenesis Journal of Endocrinology 104 $241-250$

Knox KL and Schwartz NB (1992) RU486 blocks the secondary surge of folliclestimulating hormone in the rat without blocking the drop in serum inhibin Biology of Reproduction 46 220-225

Labhsetwar AP (1969) Influence of progesterone on the pituitary and plasma levels of LH and FSH in the female rat Biology of Reproduction 1 189-196

Louvet J-P, Harman SM, Schreiber JR and Ross GT (1975) Evidence for a role of androgens in follicular maturation Endocrinology 97 366-372

Neumann F, von Berswordt-Wallrabe R, Elger W, Steinbeck H, Hann JD and Kramer M (1970) Aspects of androgen-dependent events as studied by antiandrogens Recent Progress in Hormone Research 26 337-410

Osman P (1985) Rate and course of atresia during follicular development in the adult cyclic rat Journal of Reproduction and Fertility 73 261-270
Ramirez VD and Sawyer CH (1974) A sex difference in the rat pituitary FSH response to unilateral gonadectomy as revealed in plasma radioimmunoassays Endocrinology 94 475-482

Rao IM and Mahesh VB (1986) Role of progesterone in the modulation of the preovulatory surge of gonadotropins and ovulation in the pregnant mare's serum gonadotropin-primed immature rat and the adult rat Biology of Reproduction 35 1154-1161

Richards JS and Bogovich K (1982) Effects of human chorionic gonadotropin and progesterone on follicular development in the immature rat Endocrinology 111 1429-1438

Rivier C, Meunier H, Roberts V and Vale W (1989) Possible involvement of inhibin in altered follicle-stimulating hormone (FSH) secretion during dissociated luteinizing hormone ( $\mathrm{LH})$ and $\mathrm{FSH}$ release: unilateral castration and experimental cryptorchidism Biology of Reproduction 41 967-981

Sánchez-Criado JE, López F and Aguilar E (1986) Pituitary regulation of corpus luteum progesterone secretion in cyclic rats Endocrinology 119 1083-1088

Sánchez-Criado JE, Bellido C, Galiot F, López FJ and Gaytan F (1990) A possible dual mechanism of the anovulatory action of antiprogesterone RU486 in the rat Biology of Reproduction 42 877-886

Sánchez-Criado JE, Bellido C, López FJ and Galiot F (1992a) Antiprogesterone RU486 induces dissociation of LH and FSH secretion in the cyclic rat: effect of anti-inhibin serum Journal of Endocrinology 134 43-49

Sánchez-Criado JE, Uilenbroek JThJ and de Jong FH (1992b) Antiprogesterone RU486 increases serum immunoreactive inhibin levels and LH:FSH and testosterone:oestradiol ratios in cyclic rats Joumal of Endocrinology 134 51-57

Schreiber JR and Ross GT (1976) Further characterization of a rat ovarian testosterone receptor with evidence for nuclear translocation Endocrinology 99 $590-596$

Taya K, Terranova PF and Greenwald GS (1981) Acute effects of exogenous progesterone on follicular steroidogenesis in the cyclic rat Endocrinology 108 $2324-2330$

Uilenbroek JThJ (1991) Hormone concentrations and ovulatory response in rats treated with antiprogestagens Journal of Endocrinology 129 423-429

Uilenbroek JThJ and van der Linden R (1984) Effects of prolactin on follicular oestradiol production in the rat Journal of Endocrinology 102 245-250

Uilenbroek JThJ, Sánchez-Criado JE and Karels B (1992) Decreased luteinizing hormone-stimulated progesterone secretion by preovulatory follicles isolated from cyclic rats treated with the progesterone antagonist RU486 Biology of Reproduction 47 368-373

Van der Schoot P, Bakker GH and Klijn JGM (1987) Effects of the progesterone antagonist RU486 on ovarian activity in the rat Endocrinology 121 1375-1382

Welschen R, Dullaart J and de Jong FH (1978) Interrelationships between circulating levels of estradiol-17 $\beta$, progesterone, $\mathrm{FSH}$ and $\mathrm{LH}$ immediately after unilateral ovariectomy in the cyclic rat Biology of Reproduction 18 421-427

Zeleznik AJ, Midgley AR, Jr and Reichert LE, Jr (1974) Granulosa cell maturation in the rat: increased binding of human chorionic gonadotropin following treatment with follicle-stimulating hormone in vivo Endocrinology 95 818-825

Zeleznik AJ, Hillier SG and Ross GT (1979) Follicle-stimulating hormoneinduced follicular development: an examination of the role of androgens Biology of Reproduction 21 673-681 